\title{
Holocene regressive deposits evaluation using GPR in Grumari's coastal plain
}

Talissa Mira*1, Saulo S. Martins ${ }^{2,4}$, Suelen Gouvêa ${ }^{3}$ and Francisco Dourado ${ }^{1}$. UERJ-PPGG ${ }^{1}$, UFRRJ-DPG ${ }^{2}$, UFF-PPG-DOT ${ }^{3}$, INCT-Criosfera ${ }^{4}$

Copyright 2019, SBGf - Sociedade Brasileira de Geofísica

This paper was prepared for presentation during the $16^{\text {th }}$ International Congress of the Brazilian Geophysical Society held in Rio de Janeiro, Brazil, 19-22 August 2019.

Contents of this paper were reviewed by the Technical Committee of the $16^{\text {th }}$ International Congress of the Brazilian Geophysical Society and do not necessarily represent any position of the SBGf, its officers or members. Electronic reproduction or storage of any part of this paper for commercial purposes without the written consent of the Brazilian Geophysical Society is prohibited.

\begin{abstract}
The Grumari region is marked by the presence of a coastal plain developed during the Quaternary, from the balance between the sedimentary supply and the mean sea level variation. The adjacent areas represent barrier-islands systems, which makes some authors consider the possibility of the same type of evolution in Grumari, however, there is also the possibility that the development of the coastal plain could have occurred through the formation of a strandplain. Through the GPR method, it was possible to investigate and characterize the deposits that represent the most recent evolution of the area, marked by the sea level regression and the coastline advance towards the sea. The radarfacies that represent the regressive deposits were interpreted as prograding wedges, and between them, inter-ridge deposits were identified, in which one of them could have been developed a pond.
\end{abstract}

\section{Introduction}

The Grumari region (Figure 1) is located in the western zone of Rio de Janeiro city, and is marked by the presence of a quaternary coastal plain, surrounded by pre-cambrian rocky mountains, which has been developed from the balance between sedimentary supply and mean sea level variations, scenery seen throughout the state.

Coastal plains can be developed, and exposed, during the regression regime, basically through two processes: by the formation of a barrier island system, in which the sandy barriers are separated from the mainland by a lagoon; or by the formation of a strandplain, in which the sandy ridges are not separated from the mainland, but may eventually develop lagoons in the inter-ridge space (Villwock et al., 2005).

Due to the anthropization in the 1960s in Grumari, and the lack of outcrops, its evolution during the last regression, and the formation processes involved, are not very clear, and has not been well defined yet. Pereira et al. (2012) suggest that Grumari is in the same evolution context of the adjacent areas, Restinga da Marambaia and Baixada de Jacarepaguá, that is, it is an old barrier island system. However, there is still the possibility of the area being a strandplain.

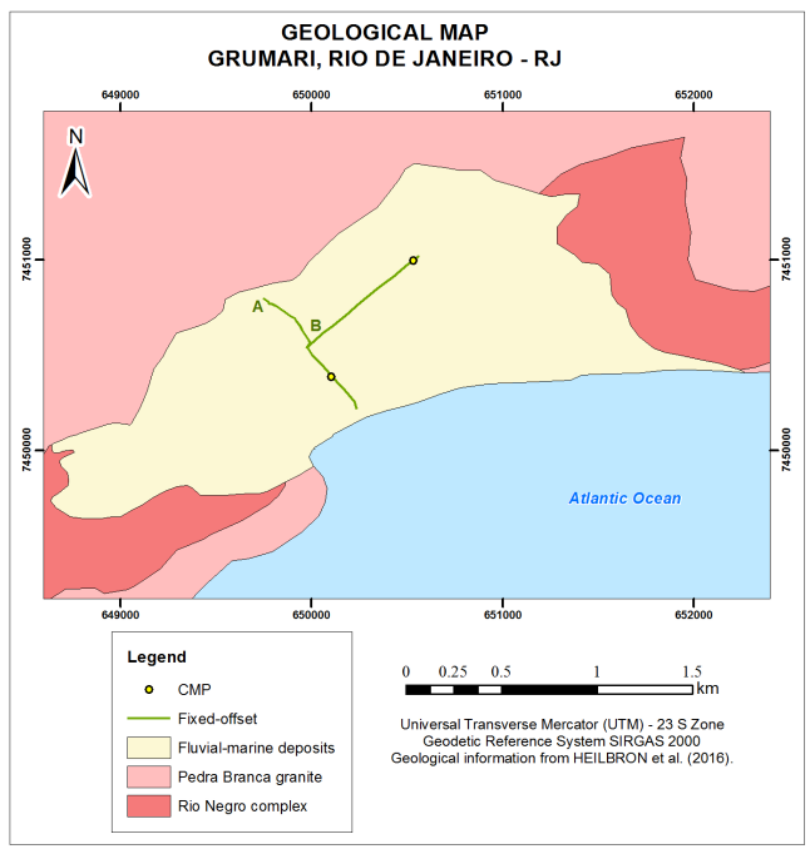

Figure 1 - Geological map of Grumari region and GPR acquisition location.

Several authors have used the Ground Penetrating Radar (GPR) geophysical method in the coastal evolution studies, such as Leatherman (1987), Neal \& Roberts (2000) Bristow \& Pucillo (2006), and Berton et al. (2018). This method allows indirect investigation of the subsurface from the emission of electromagnetic waves that, upon being received by the receiving antenna, record the response of the medium electrical properties through an image (Annan \& Cosway, 1992). Because of the two-dimensional observation, it is possible to analyze the distribution of radarfacies that can later be correlated with possible sedimentary deposits.

The objective of this work is to apply the GPR method to investigate the most recent deposits in the area, that is, the deposits formed in the holocene regression regime, searching for traces that could help to classify the evolution of the area as a barrier island system or a strandplain. This investigation is done through the characterization of the radarfacies that represent those deposits, allowing the definition of sedimentary processes involved and the probable paleo-environment. 


\section{Field work and Data Processing}

In the field work phase, two fixed-offset GPR data were obtained, exhibiting the distribution of sedimentary deposits in subsurface. The data were called Section A, and Section B (located geographically on the map of Figure 1), being the first one with shore-normal direction, and the other parallel to the coastline. The equipment was a MALÅ Geoscience Ground Penetrating Radar, of unshielded antennas, with $100 \mathrm{MHz}$ frequency, and arrangement parallel to the survey direction (TM mode). The acquisition was done in time mode, every 1 second, in order to obtain as many traces as possible avoiding aliasing. With the GPR equipment, a Differential Global Positioning System (DGPS), Hyper GGD type, from Topcon, was used to geographically position the GPR traces and calculate the final distance of the section. Coordinates and altitude were also collected every 1 second along the course.

In addition to the fixed-offset, CMP data were acquired in order to obtain the 1-D velocity model for each of the fixedoffset sections. From the velocity models, it is possible to convert the time in depth and the migration in the sections processing. For this acquisition, the GSSI SIR 3000 was used, with 100Mhz frequency antennas, unshielded, with arrangement perpendicular to the survey direction (TE mode). The receiving and transmitting antennas were spaced $10 \mathrm{~cm}$ apart for each side, totaling at the end $20 \mathrm{~m}$ distance between them, with 700ns time window. Acquisitions were made at two different points (also geographically located in Figure 1), according to the location of the previously acquired sections.

The processing of the fixed-offset and CMP data was performed in the Reflex-Win software and required different processing routines since they were different types of acquisition and equipment.

After data processing (Fixed-offset and CMP), 1-D velocity models were generated from the CMP data. The construction of velocity models and the mathematics behind the processes involved can be found in the literature by Tillard \& Dubois (1995), Greaves, et. al (1996), Forte et. al (2014) and in the third chapter of Yilmaz's book (2001).

The 2-D velocity models was built from the 1-D velocity models and its lateral extrapolation. That is, for each fixedoffset GPR section, a velocity model with the same dimensions ( $x$ and $y$ ) was built, but without the lateral velocity variation $(\mathrm{x})$, only time variation $(\mathrm{y})$. After constructing all 2-D velocity models, it was possible to migrate in all fixed-offset sections using the Kirchhoff 2D migration.

The GPR data interpretation were based on the radarfacies definition of Gawthorpe et al. (1993) and the seismicstratigraphic interpretation concepts of Mitchum Jr. et al. (1977). Firstly, the regional reflectors and those of higher amplitude were identified; subsequently, the external geometry that delimited a certain set of less prominent reflectors, and, later, its internal reflection pattern.
As the radarfacies represent the sedimentary structures and rocks in subsurface, we tried to interpret the type of sedimentary deposit geophysically represented in the section, and the geological processes involved in its formation.

\section{Results and Discussions}

Section A (Figure 2) is $620 \mathrm{~m}$ in length and is located in the central portion of the coastal plain, extending to the current beach ridge. Figure 3 shows, in detail, the radarfacies found in this section.

Between 3 and $7 \mathrm{~m}$ deep, it was defined the radarfacies $\mathrm{R} 1$. The external geometry is a sigmoid-type clinoform, and internally it is possible to observe some reflectors with downlap terminations towards the sea. It was possible to identify at least eight radarfacies of this type in the same depth range, prograding from the land towards the sea.

Radarfacies R1 was interpreted as sediments deposited towards the sea, in a subaquatic environment, and, for this reason, were classified as prograding wedges. The sequence of several prograding wedges shows the progradation of the coastline in the marine regression regime.

Between two R1 radarfacies sigmoids, in 4-6m deep, was identified a R2 radarfacies, presenting an apparently triangular external geometric form, and internal reflectors not very well defined, with low amplitude, and apparently chaotic.

The $\mathrm{R} 2$ radarfacies represents a sediment accumulation between two $\mathrm{R} 1$ sigmoids, that is, probably in an inter-ridge area. It was not possible to define the internal pattern of reflection, which approaches the chaotic, however, it is noticed that there is no plane-parallel lamination typical of lagoon and, therefore, it is not a floodable inter-ridge.

At the end of the section, it was defined the $\mathrm{R} 3$ radarfacies, between 3 and $5 \mathrm{~m}$ deep, which presents external geometric pattern in the form of a tabular depression at the base, bounded by a plane-parallel reflector at the top. The internal plane-parallel reflection pattern, and all the reflectors shows high amplitude.

R3 radarfacies was also interpreted as an inter-ridge deposit, different from the R2 though. In this case, we believe that the inter-ridge region was floodable, and possibly formed a pond. The characteristic that led to this interpretation is the plane-parallel reflectors, indicating a slow sediment deposition, which occurs in humid environments. 


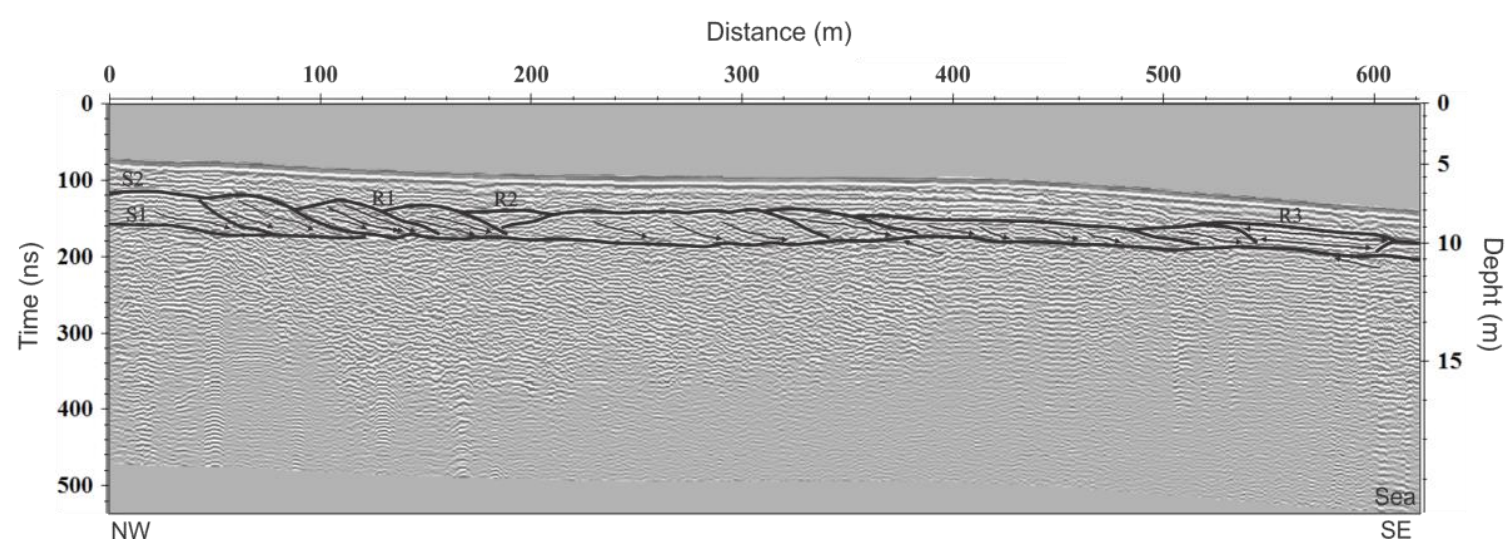

Figure 2 - Section A.
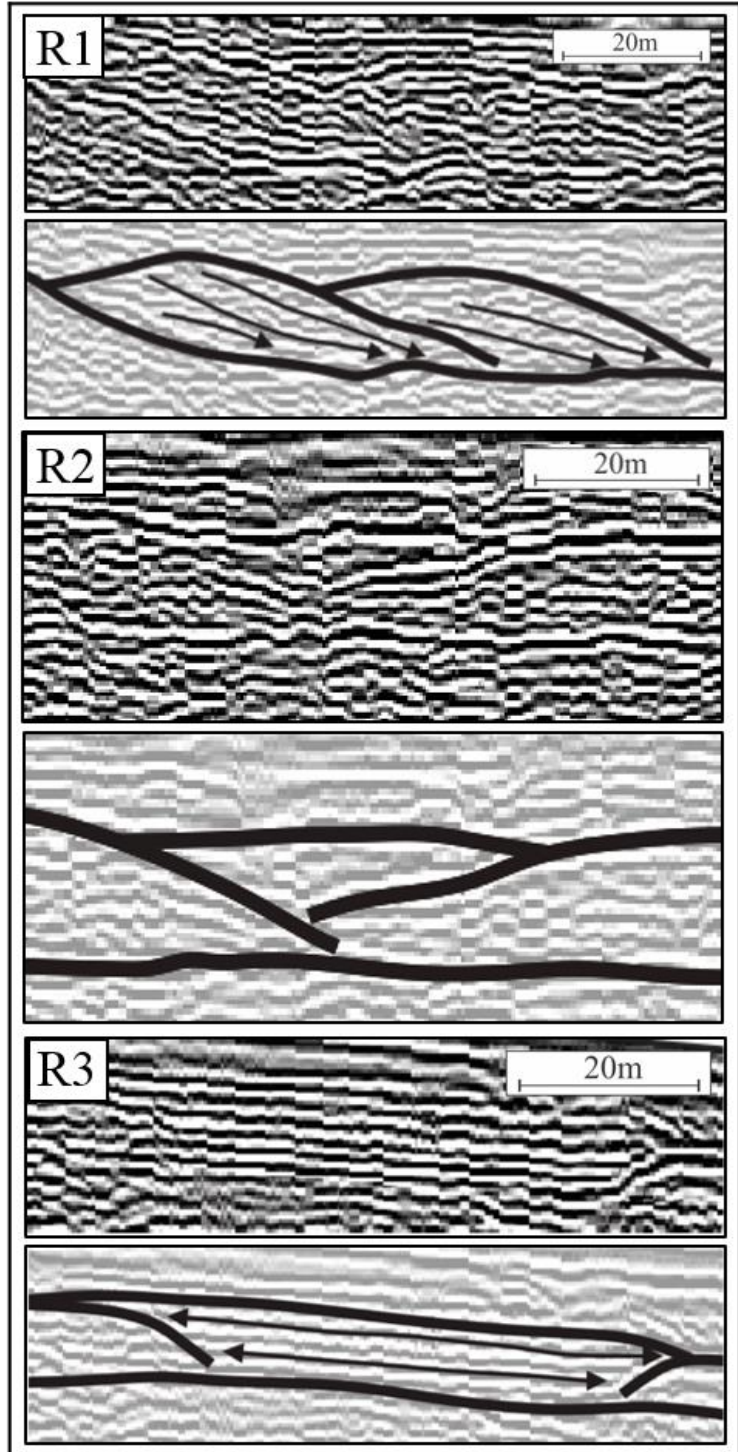

Figure 3 - Radarfacies of Section A
In addition to the radarfacies above, two high-amplitude, continuous, relatively flat-parallel reflectors were mapped extending over almost the entire section. The S2 surface is $4 \mathrm{~m}$ deep and, although it is plane-parallel, in general, in some portions it tends to follow the morphology of the radarfacies that lies below it, like the sigmoids of the R1 radarfacies. The $\mathrm{S} 1$ surface is located at $6 \mathrm{~m}$ deep, on average, remaining flat-parallel and continuous throughout the section. The S2 marks the top of the investigated deposits, while the $\mathrm{S} 1$ marks the base.

Section B (Figure 4) is $760 \mathrm{~m}$ in length, and is parallel to the coastline, representing a strike view of the Section A radarfacies. The Figure 5 shows in detail the radarfacies interpreted in these sections.

The $\mathrm{R} 4$ radarfacies is between 3 and $6 \mathrm{~m}$ deep. It is formed by a set of reflectors that does not have well defined external geometry, however, it is noted that this is limited at the top and base by the surfaces S1 and S2 that remain plane-parallel and continuous along the section. The internal reflectors are discontinuous and of variable amplitude, with a plane-parallel pattern, in general, and chaotic in some portions.

As $\mathrm{R} 4$ radarfacies corresponds to the strike view of $\mathrm{R} 1$ radarfacies, they also represent the prograding wedges, and show the longitudinal continuity of these features along the central portion of the plain, without interruptions.

The strike sections also show the continuity of the main reflectors mapped in the area, being S2 surface at $3 \mathrm{~m}$ depth, and $\mathrm{S} 1$ at $6 \mathrm{~m}$. The continuity of these surfaces allows their classification in regional geophysical surfaces, distributed throughout the central part of the plain. We believe that these geophysical surfaces are stratigraphic bounds that delimit the base and top of the regressive deposits of the most recent portion of the area. The S2, at the top of the prograding wedges, was geologically interpreted as subaerial discordance, and the $\mathrm{S} 1$, at the base, as an erosional surface. 


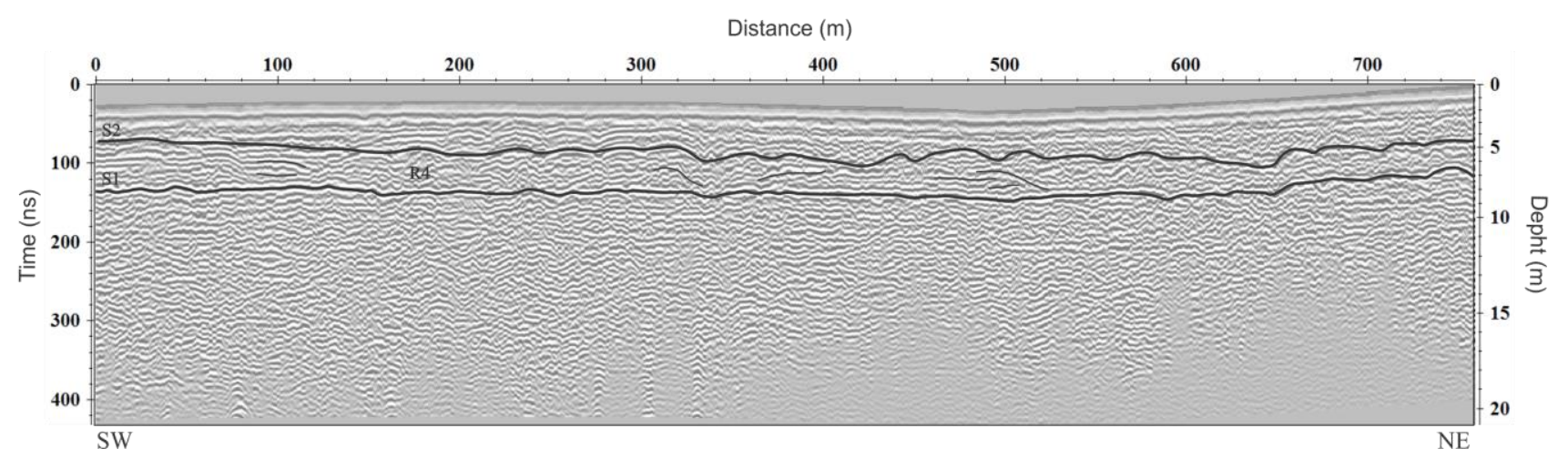

Figure 4 - Section B.

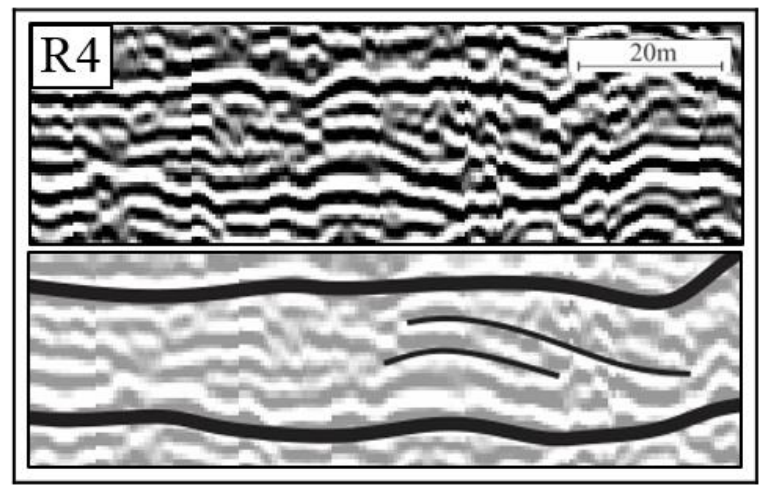

Figure 5 - Radarfacies of Section B.

\section{Conclusions}

Through the acquisition, processing and interpretation of GPR data, four radarfacies and two regional surfaces were identified and characterized in 2 sections, distributed throughout the central portion of the plain. The radarfacies distribution in Section A shows what could represent the regressive deposits of the region, and sections $\mathrm{B}$ confirm their distribution throughout the coastal plain.

Radarfacies interpreted as prograding wedges (R1) were interpreted as sandy ridges connected to each other, with the presence of either a non-swellable (R2), and a floodable (R3) inter-ridge area, in which a pond was developed. S1 and S2, in Section A, shows the sandy ridges evolution from the mountains towards the sea. The longitudinal continuity of the sandy ridges, exhibited in R4, limited by $\mathrm{S} 1$ and S2 in Section B, emphasizes the hypothesis that these wedges are sandy ridges that extend across the plain, parallel to the coastline.

The methodology followed led to the conclusion that the Holocene sedimentary evolution of the Grumari coastal plain, from the most recent regressive regime, probably occurred from the development of sandy ridges, sometimes attached to each other, sometimes separated by an inter-ridge area and, therefore, is characterized as a strandplain.

\section{Acknowledgments}

The author thanks FAPERJ for financial support during the fieldwork campaign. All the authors thanks LABSISMO (UERJ), CEPEDES (UERJ), LEXMIN (UERJ), and LAMEMO (COPPE/UFRJ) for the equipment, software, and work environment. This work was supported by CAPES.

\section{References}

ANNAN, A P.; COSWAY, S.W. Ground Penetrating Radar Survey Design. Annual Meeting of SAGEEP, Chicago, EUA, 1992.

BERTON, F., GUEDES, C. C. F., VESELY, F. F., SOUZA, M. C., ANGULO, R. J., ROSA, M. L. C. C., \& BARBOZA, E. G. Quaternary coastal plains as reservoir analogues: Wave-dominated sand-body heterogeneity from outcrop and ground-penetrating radar, Central Santos Basin, Southeast Brazil. Sedimentary Geology, 2018.

BRISTOW, C. S.; PUCILLO, K. Quantifying rates of coastal progradation from sediment volume using GPR and OSL: the Holocene fill of Guichen Bay, south-east South Australia. Sedimentology, v. 53, n. 4, p. 769-788, 2006.

FORTE, E., DOSSI, M., PIPAN, M., COLUCCI, R. R. Velocity analysis from common offset GPR data inversion: theory and application to synthetic and real data. Geophysical Journal International, v. 197, Issue 3, p. 1471-1483, 2014.

GAWTHORPE, R. L.; COLLIER, R. E. L.; ALEXANDER, J.; LEEDER, M.; BRIDGE, J. S. Ground Penetrating Radar: application to sandbody geometry and heterogeneity studies. In: NORTH, C.P.; PROSSER, D.J. (Eds), Characterization of Fluvial and Aeolian Reservoirs: Spec. Publ. Geol. Soc. 73, 421-432, 1993.

GREAVES, R. J.; LESMES, D.P.; LEE, J. M.; TOKOZ, M. $N$. Velocity variations and water content estimated from multi-offset ground penetrating radar. Geophysics, 61, 
683-695, 1996.HESP, P. A gênese de cristas de praias e dunas frontais. Mercator, v. 1, n. 2., 2002.

LEATHERMAN, S. P. Coastal geomorphological applications of ground-penetrating radar. Journal of Coastal Research, v. 3, n. 3, 1987.

MITCHUM JR., R. M., VAIL, P.R., SANGREE, J.B. Seismic Stratigraphy and global changes of sea level, part. 6: stratigraphic interpretation of seismic reflection patterns in depositional sequences. In: PAYTON, C.E. (ed). Seismic stratigraphy - applications to hydrocarbon exploration. Tulsa, AAPG, p. 117-133 (Memoir 26), 1977.

NEAL, A. \& ROBERTS, C. L. Applications of groundpenetrating radar (GPR) to sedimentological, geomorphological and geoarchaeological studies in coastal environments. Geological Society, London, Special Publications, v. 175, n. 1, p. 139-171, 2000.

PEREIRA, E.; BRAGA, P.; MENDES, C.; BERGAMASCHI, $S$. Sedimentação quaternária na planície costeira de Jacarepaguá e Guaratiba (Estado do Rio de Janeiro). In: RODRIGUES, MAC; PEREIRA, SD; SANTOS, S. B. Baía de Sepetiba: Estado da Arte. Rio de Janeiro, Editora Corbã, 2012.

TILLARD, S.; DUBOIS, J.C. Analysis of GPR data: wave propagation velocity determination. J. Appl. Geophys., 33, 77-91, 1995.

VILLWOCK, J. A.; LESSA, G. C.; SUGUIO, K.; ÂNGULO, R. J.; DILLENBURG, S. R. Geologia e Geomorfologia de Regiões Costeiras. In: SOUZA, C.R., SUGUIO, K., OLIVEIRA, A.M., OLIVEIRA, P.E. Capítulo 5. Quaternário do Brasil. Holos Editora, p. 94-113, 2005.

YILMAZ, O. Seismic data analysis: Processing, inversion, and interpretation of seismic data. SEG, 2093p., 2001. 